\title{
The influence of the natural environment on the transformation of architectural style
}

\author{
Yulia Ivashko ${ }^{1}$, Tetiana Kuzmenko ${ }^{2}$, Li Shuan ${ }^{3}$, Chang Peng 4 , \\ ${ }^{1,4}$ Kyiv National University of Construction and Architecture, Ukraine, \\ ${ }^{2}$ National University "Yuri Kondratyuk Poltava Polytechnic", Ukraine, \\ ${ }^{3}$ Zhejiang University of Technology, China
}

\begin{abstract}
The article explores the phenomenon of the architecture style transformation with a radical change in the natural environment. By the example of two pairs of objects of the same style objects of Northern National Romanticism in Finland and China and objects of the "Moscow pattern work" in Russia and France, the non-identity of the their architecture perception is argued with the general preservation of the defining signs of style - severe stone forms of northern national romanticism in dense Helsinki's urban development is perceived differently than similar forms of northern national romanticism among the exotic greenery of the coastal city of Qingdao, just as finely detailed forms of the Moscow Orthodox churches are perceived differently than similar forms among the palms of Nice. Another aspect is associated with a change in the ideological perception of the style of architecture when it is transferred to the territory of another country. Thus, Northern National Romanticism was perceived by Finland and the Baltic countries as the style of their national identity, therefore, it clearly expressed those elements and plots that just expressed the national identity of the countries under the rule of the Russian Empire. The same style, embodied in the representative buildings of Qingdao, primarily the governor's residence, expressed a different ideology: Qingdao was the military base of the navy, therefore Northern National Romanticism in this case expressed the nationality and dominance of Germany. At the same time, as you move away from the center of origin, each style invariably transforms as a result of multiple local layers, therefore, with all the grandeur of the appearance of the residence, it does not look as monumental as similar buildings in Finland or the Baltic countries due to the influence of Chinese traditions in polychrome and decor and placement in a different natural environment.
\end{abstract}

Keywords: natural environment, influence, Northern National Romanticism, perception of style

\section{Introduction}

Hypothesis, proven by this research, is that the natural environment in some case is not only a successful addition to the object of architecture; it can fundamentally change the perception of style. Therefore, such objects will be perceived differently in a diverse modern landscape. The mentioned is typical for objects of various functional purposes religious buildings, public or residential buildings, small architectural forms. As examples, we selected pairs of objects of different functional purpose, located in diverse parts of the world, but similar in style. The Saint Nicholas Cathedral in Nice is compared to the Church of the Holy Trinity in Nikitniki in Moscow; the former residence of the Governor of Qingdao in China, a representative government house, is compared with the Helsinki's Pohjola Insurance building. If we analyse why these or other churches among the rest leave a particularly strong emotional impression and are remembered for many years, it becomes clear that, along with the purely canonical component - the main one in Orthodoxy, there are two others-successful urban planning, natural surroundings and a memorable unusual architectural appearance. The same goes for public and government buildings.

The successful urban planning of an object in an urban environment is the creation of beautiful views from various streets, a picture from a hill, visibility from a long distance, as well as picturesque nature, which in this case plays the role of a kind of theatre backstage to represent an architectural object.

In article was determined the group of outside factors and conditions, which predominated the transformation of styles. At the base of methodology of the systematicstructural analyse there were investigated the semantic properties of the architectural forms of buildings. On the basis of the methodology of the system-structural analysis, the principles of location of objects in the urban environment, planning schemes are determined, the basic elements of styles are analysed and systematized, the structural layouts and decoration are studied. Objects are analysed from the enlarged urban-planning level (location in the urban environment) to the object level. 


\section{The role of the natural environment in the transformation of the perception of the Nordic National Romantic Style}

As the first example, we will consider how the perception of National Romanticism - the national style of Finland, Northern Germany, Scandinavia and the Baltic countries - changed when it was transferred to the territory of China's settlements, a country with rich local architectural, construction and landscape traditions, into fundamentally different natural climatic conditions.

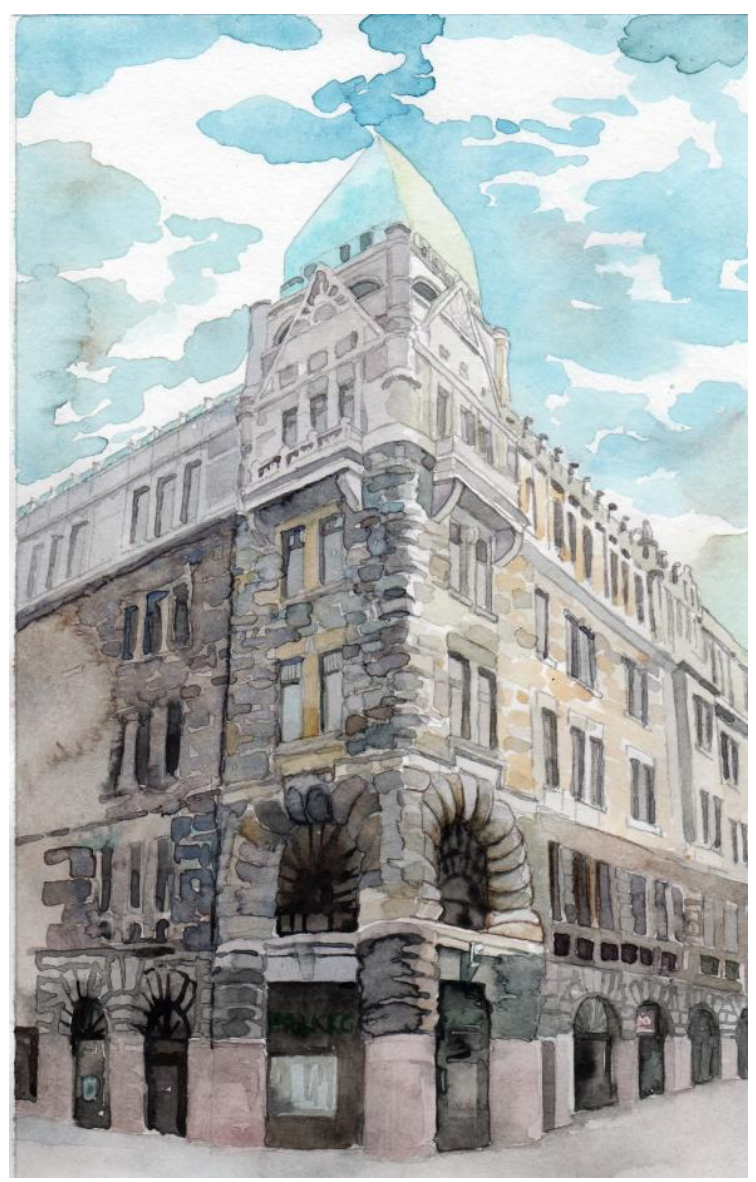

Fig.1. Pohjola Insurance Company Building in Helsinki. Watercolour by Chang Peng, 2019

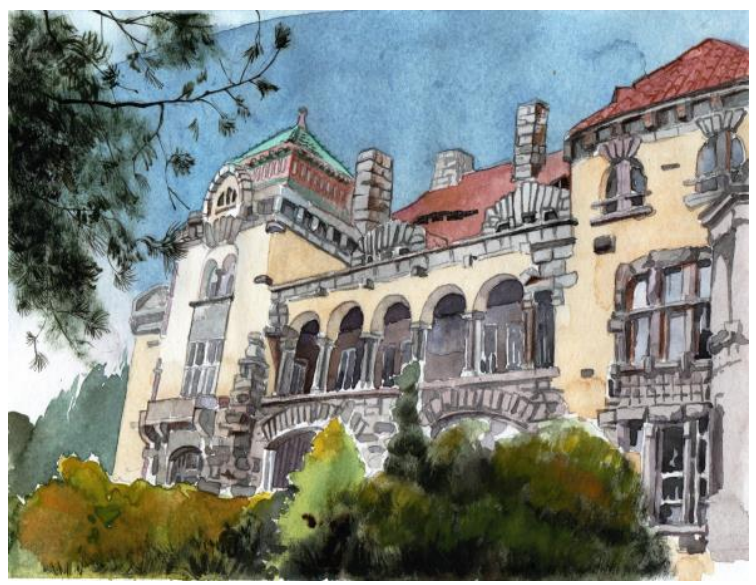

Fig. 2. The residence of the governor of Qingdao. Watercolour by Chang Peng, 2019
The Nordic National Romantic Style is one of the varieties of National Romanticism as a whole, as a separate direction $[1 ; 4 ; 10 ; 11 ; 13]$. National Romanticism spread in European architecture in the second half of the 19th century and was associated with the search for national identity, and it was especially active in those countries that thus realized their desire to free themselves from foreign domination and at the same time strengthen national culture. The emergence of National Romanticism is associated with an increase in interest in the heritage of Romanesque architecture (it is noteworthy that this interest was also cultivated by historical novels about this era, primarily Walter Scott's books). Steeped in the severe note of knightly valour, the era of the early Middle Ages became a source of inspiration for the American architect G. Richardson, who, based on it, created his version of "Neo-Roman" architecture, opposing it to Neo-Gothic with its desire for extreme decoration, dominating in the second half of the 19th century.

The Romanesque architecture of Germany with its massive rude forms became the source for National Romanticism (the so-called "Nordic style") in Germany. The buildings of G. Richardson, the Romanesque architecture of Germany (and France), German National Romanticism of the second half of the 19th century, the English rationalist Art Nouveau and the Arts and Crafts movement, combined with the themes of Finnish folklore, became the basis for the development of Finnish National Romanticism in the early 1890s (Fig. 1).

Similar phenomena arose in other Scandinavian countries - Sweden and Norway; however, it was Finland that gave the world the most vivid image of Scandinavian National Romanticism. The chief creators of the new style were Onni Tarjanne, Lars Eliel Sonck, Akseli Gallen-Kallela, Gottlieb Eliel Saarinen, Herman Ernst Henrik Gesellius, Armas Eliel Lindgren.

As a result, the main signs of Northern National Romanticism were formed, which subsequently passed into the modernist style of St. Petersburg, which was called "Nordic" $[4 ; 10 ; 11]$ :

1) composition: dynamic asymmetry with a dominant; large scale; emphasized tectonics through the use of national stone - granite, often in the form of raw blocks; active silhouette with towers, gables, bay windows with towers;

2) elements: towers with motifs of Romanesque medieval castles, multi-store bay windows of various shapes with original crowning, finishing stone working of walls and unusual decor, trapezoidal or egg-shaped windows and entrances;

3) decorative methods - special deliberately rough-textured processing and decor with motifs of pine branches and cones, bears, lynxes, heroes of Finnish and Swedish folk tales. 
Northern Art Nouveau of Saint Petersburg distinguished by severity, monumentality, restrained monochromaticity, the use of natural stone (granite, Swedish slate) on facades with various finishing (rock-faced rustication, smooth rustication), overhanging the massif of the entrance part, as if "cut out" in the rock. The low-relief decor in the technique of stone carving came from Scandinavian culture and legends - with images of predatory animals, fish, snakes, spiders, mushrooms, fantastic humanoid creatures.

The Art Nouveau architecture of St. Petersburg had a strong influence on the Art Nouveau architecture of Central and Eastern Ukraine, especially because most of the Kyiv and Kharkiv architects were graduates of the St. Petersburg Institute of Civil Engineers or the St. Petersburg Academy of Arts, and there was a practice of inviting famous architects to fulfil high-prestige private orders.

In Art Nouveau of China, the international trends of European Art Nouveau are intricately intertwined with traditional Chinese architecture, giving rise to the original phenomenon of Art Nouveau in China $[5 ; 6 ; 7 ; 8 ; 9 ; 14 ; 15 ; 16]$. In the modernity of Qingdao, an original phenomenon arose in representative buildings - a peculiar Chinese interpretation of northern (namely, Germanic) national romanticism. This phenomenon is unusual also because in the Russian territories, where St. Petersburg architects and graduates of St. Petersburg educational institutions worked, it did not receive such a distribution. It can be assumed that the presence of local grey granite deposits, a cheap building material, also contributed to this.

The unique character of the phenomenon of Northern National Romanticism in China lies in the fact that this movement originated and spread at a large distance from the northern countries, in completely various climatic and cultural conditions, which entailed the transformation of one of the most distinctive branches of Art Nouveau as it applies to the Chinese conditions. It is a unique fact that eclecticism is present to a much lesser extent in Northern National Romanticism of Qingdao than in the objects of other varieties of Art Nouveau in China. Were studied the historical reasons of appearance of the Art Nouveau objects at the European settlements territory in China and was observed the influence of the outside factors (the economical, political, religional and national) on the style's transformation and specific of Art Nouveau forming in Chinese architecture. Was analysed and argued the influence of the natural landscape to Art Nouveau transformation in China. Was argued the correlation of national and regional in the North National Romanticism in China.
There is much to say, that even in the best objects of Northern National Romanticism in Qingdao there are features unusual for the original Northern National Romanticism; however, the architects managed to achieve the chief thing: their objects seem successful quotes, stand out for their scale and monumentality, and demonstrate the possibility of combining Northern National Romanticism and Chinese architectural and artistic traditions. It should be noted that such an astonishing mix of "northern" Germanic style and "eastern" Chinese is not perceived as tasteless and ordinarily fits into the natural environment.

Among the objects of Northern National Romanticism in China, the residence of the governor of Qingdao keeps an exceptional place due to the unique synthesis of German rules of park art and local landscape traditions that have been formed in China for millennia [16, 68-69; 17] (Fig. 2). The governor's residence seems to be standing above the dragon's lair, since the mountain itself is called "Dragon", and the roads along the southern slope, leading to the governor's residence and connecting it with the foot of the mountain, are "dragon's". It is the synthesis of the ancient Chinese name of the mountain - "Dragon" and the Scandinavian and German early medieval epics, that explaines the presence of a roof hanging from the cornice over the main entrance of the stone dragon's residence.

The image of the dragon is present in the medieval Germanic epic poem of the $12^{\text {th }}-13$ centuries, "The Song of the Nibelungs". Fafnir (ancient Fáfnir) is at the same time a hero of Scandinavian myths, where he is considered the son of the sorcerer Hreidmar, who later assumed the form of a dragon.

Dragon Fafnir was considered the keeper of magic gold. His name is mentioned in the sagas "Poetic Edda", "Younger Edda", "The Saga of the Völsungs", "The Song of the Nibelungs". Richard Wagner makes him the character of his opera "The Ring of the Nibelungs".

The residence building was built on the southern slope of the Dragon Mountain and is fully visible from the top. Thus, the thoughtful top view of the building with tower volumes, stone chimneys and plastic of different heights with crowned and pitched roofs with greenish and red tiles and red wooden details characteristic of China is of particular importance.

The monumentality of the building is largely due to its three-dimensional composition. The main facade with an open gallery of the second floor is oriented to the south, the central entrance is on the west side.

The yellow plastered surfaces of the external walls have a textured finish in the form of regularly repeated wavy lines; the facade elements are 
reinforced by contrasting different textures (stone plaster), ornaments and gables; and the plastics technique is used for uneven different-height protruding and recessed volumes combined into a single whole.

Although this "castle-like" building is much younger than European castles, it seems to be related to them in style.

After the liberation in 1957, the building was again returned to China and was a government residence; during the residency of President Mao in it in July-August 1957, the meetings of the Politburo were held in the house. Since 1999, it turned into a museum with open visits, recognized as a monument of national significance and taken under state protection.

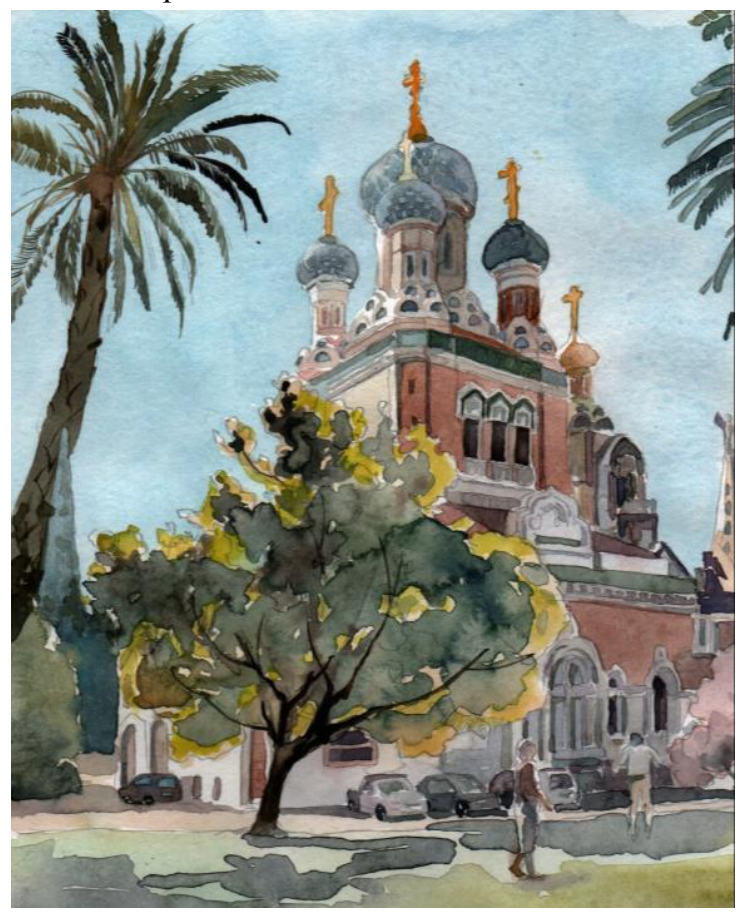

Fig. 3. St. Nicholas Cathedral in Nice. Watercolour by Chang Peng, 2019

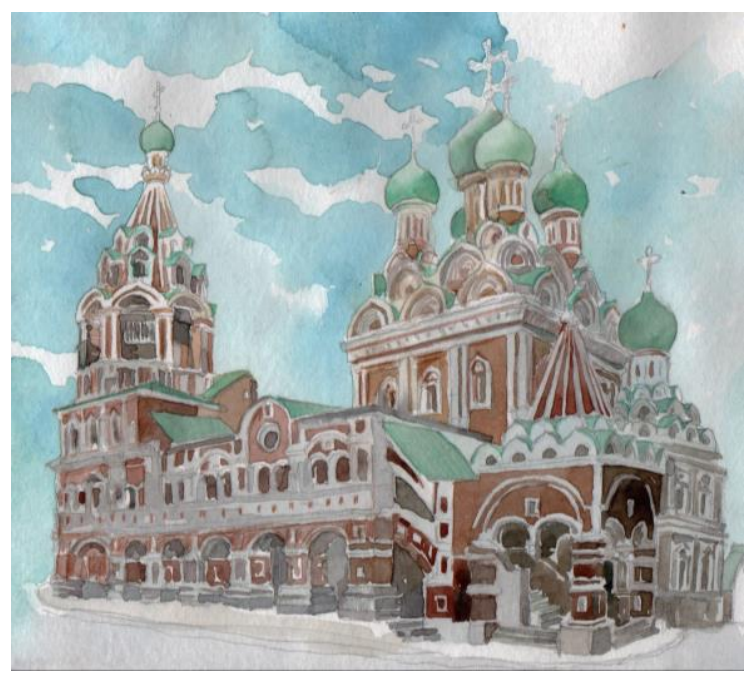

Fig. 4. St. Trinity Church in Nikitniki in Moscow. Watercolour by Chang Peng, 2019
In objects using the motives of Northern National Romanticism in China, the decorative function in the interpretation of towers and crowning mostly goes to building materials, since in many cases they become the principal expression of decorative qualities (roof tiles, towers' finishing with rock-faced stone).

\section{The role of the natural environment in the transformation of the perception of the style of the "Moscow pattern-work" ("Moscow uzorochie")}

When we spoke about the fact that for many cathedrals the urban planning and nature around the temple is an important factor, all of the above fully applies to St. Nicholas Cathedral in Nice, which is the principal figure of the city, and at the same time a symbol of the total foreign Russian Orthodoxy. By the example of St. Nicholas Cathedral, one can trace how placing an object in the Moscow patternwork style among exotic greenery and palm trees completely change its visual perception, it can be seen when comparing St. Nicholas Cathedral in Nice (Fig. 3) and St. Trinity Church in Nikitniki in Moscow [12] (Fig. 4).

Just approaching the cathedral, you can see from afar against the backdrop of picturesque mountains with greenery and villas scattered along the slopes, its expressive patterned and detailed silhouette of a complex outline, aimed at the bright blue sky with ceramic blue-green domes with gilt openwork crosses [12]. The cathedral can be seen from above, from the hill, from different points; it is slightly covered by exotic Mediterranean greenery, and this unusual combination of the temple-tower in the style of the Moscow patternwork of the 17 th century and tall palm trees is especially impressive.

A distinctive perception of the temple even from afar is also facilitated by the fact that it is located on a vast, undeveloped richly landscaped area with the possibility of roundabout and rest areas with alleys and benches. This idea also has a deep meaning: the temple is so complicated in compositional form and so detailed that it needs to be read like a book, slowly and thoughtfully considering the composition of volumes, majolica friezes of modified entablature, fine detailing of majolica panels and stucco decoration of facades with geometric and phytomorphic ornaments, anthropomorphic (images of the Lord and the Mother of God) and teratological (six-winged seraphim and angels) plots, each of which contains profound sacred meaning.

It is noteworthy that the specific architectural solution of the front western facade of the cathedral is explained by a purely urban planning factor, since initially St. Nicholas Cathedral was to be built on another site, at the intersection of two streets, 
the directions of which were emphasized by two porches with entrances [12]. After the construction of the temple on another site, such a non-standard solution of the entrance part gave the volumetric composition a particular expressiveness and dynamism. Besides, the classic architectural technique, providing a circular walk around the object and its full façade, is setting the volume at the corner. Thus, the angular placement of the two porches provided a circular view of the temple and enriched its composition.

The architectural appearance of St. Nicholas Cathedral is unique and unusual for Russian Orthodox architecture, although during the reign of historicism-eclecticism and Art Nouveau, a free combination of compositional techniques and elements of several styles was allowed. The construction of churches in the early twentieth century simultaneously felt the influence of the traditions of previous historicism -eclecticism and innovation of Art Nouveau that arose at the end of the 19th century. It was at the turn of the century and in the first decades of the twentieth century that special attention was paid to the expression in the architectural appearance of the Orthodox church of national identity, "Russian national identity", often by explicitly moving away from the established stylistic canons by simultaneously embodying the national signs of ancient monuments of various architectural schools: in the temples of the early twentieth century there are modified forms of domes and tents, simplified and modernized entablature and cornices, different from classic samples; hypertrophied orders, often with simplified capitals and bases or without bases at all; decor in the style of paintings by V. Vasnetsov and I. Bilibin. All these features of Orthodox church architecture of the early twentieth century are fully present in the solution of the facades and interiors of St. Nicholas Cathedral in Nice.

The main idea of the temple's architecture is to embody in one object those features that express "Russian originality", "Russian identity", create the image of a temple-visiting card of Russia abroad and make it recognizable just like a Russian church abroad [12].

The cathedral is distinguished by a complicated multiaxial volumetric-spatial composition. The central axis, passing through the triple window of the western facade, the bell tower and the projection of the principal dominant chapter, and many minor axes are distinguished - two pass through the porch with tents attached to the plane of the western front facade, four through the smaller cupolas surrounding the central chapter, several through attached elements of the eastern facade, two through the portals of the northern and southern facades, three more through an open doorway with a bell, a kokoshnik above it and the cupola of the bell tower on all facades except the western one. Such multiaxial and complicated volumetric-spatial composition is not only a particular feature of the temple construction of the modern period but also a consistent reference to the structures of temples of the "Moscow pattern-work" of the 17 th century.

Two entrances are situated not on the central axis, but to the right and left sides of it, from the southwest and northwest corners. Initially, the site allocated for the construction of the temple was located on the intersection of two streets, and this arrangement of entrances was convenient. However, the cathedral was built in another part of the city, on the territory of the former Bermond Villa, the initial building plan was preserved.

The central axis is emphasised by a triple window with a gilded canopy, characteristic for the Russian pattern-work, above it, and the mosaic depicting the worship of two angels to the Holy Savior's image; an open belltower with an elegant majolica "kokoshnik" above the opening with bells and a gilded scaly roof; even higher, the principal axis is supported by the largest and highest dome on a high drum with light windows (another non-standard feature of the temple that differentiates it from Russian pattern-work churches is light windows in drums, whereas the original sanctuaries of the 17th century had only decorative cupola).

Although the temple is consistently stylistically connected with the Russian pattern-work, nevertheless, it is also associated with the pseudoRussian style of the 19th century, with the artists of Abramtsevo and Talashkino, which is especially noticeable in the majolica ornaments of a composite pattern on the walls and friezes of the cathedral.

The specific aesthetic expressiveness of the cathedral is achieved due to the harmonious correlation of the heights of the various constituent volumes; each has its crowning, and the ratio of the heights and scales of the parts of the temple also denotes a particular hierarchy - they are all subordinate to the central volume with cupolas, one of which dominates.

The architect paid particular attention to the ratio of masses and scales of elements and details. Despite the recognizability of the Russian architecture of the 17th century, the volumetricspatial composition and the solution of the facades of the cathedral differ both from the churches of Moscow pattern-work and the other of the architect M.T. Preobrazhensky. It is the peculiarity of the author's style of M.T. Preobrazhensky, who created a unique synthesis of Russian medieval temple construction, the traditions of the pseudo-Russian style of the 19th century and Art Nouveau in the temple architecture of the early 20 th century. 
The five-domed cathedral was built on the model of the Moscow five-domed churches of the XVII century (in Nikitniki and Ostankino) from light brown German brick but decorated with local materials: pink granite and blue ceramic tiles.

As mentioned earlier, the angular arrangement of the porches with marble steps and tents provides a composite connection of the facades. Although the porches are a part of the cathedral and play an essential role in the dynamism of the threedimensional composition, at the same time they create the impression of independent volumes since only one of their facades is connected to the cathedral, and the other three protrude significantly from the western facade.

From one side each porch is supported by hypertrophied massive columns, pronouncedly round in plan, with stylized foundations and pedestals. From the side of the facade, analogous low massive pilasters of similar proportions correspond to them. Among the columns and pilasters, there are arches with tympana decorated with polychrome majolica panels with a combination of teratological ornament (round medallions with the image of six-winged seraphim) and phytomorphic ornament (curved stems of plants with flowers and fruit - a definite echo of the Art Nouveau phytomorphic ornaments).

In the drawings of the ornamental decor of the cathedral facades, at the same time, the direct influence of the pseudo-Russian style of the 19th century and especially the works of V. Vasnetsov and I. Bilibin are noticeable.

The elements of the period of the "Russian pattern-work" ("Moscow pattern-work") are as follows: the tent roofs with a characteristic decorative detail - drop ornament in the form of an overturned pyramid, which supports decorative arches under the large one joining them; blind decorative cupolas; outside architraves in the form of kokoshniks; multi-tiered kokoshniks on vaults; wreathed columns; half-columns; tiled, stucco and picturesque decor.

The architect applied on the facades of St. Nicholas Cathedral a kind of "alphabet" of elements expressing Russian national identity. He used the onion-shaped domes, derived from stone churches of the 17th-century Russian pattern-work and wooden churches of the Russian North, and the tent-shaped domes; kokoshniki - semicircular false gables for decorative purposes, located in decreasing tiers at the base of the drums of cupolas; arches of various shapes - circular arches (over the porch of the western facade, portals and windows of the northern and southern facades); ogge arches (framing the triple window of the western facade, three arches of the lower tier of the eastern facade, decorative insert of the eastern facade); mitred arches (framing three windows of the upper tier of the eastern facade wall); multifoil compound arches above the open space of the bell tower, above the bells which were typical of the period of blossoming "Moscow pattern-work" ("Moscow Uzorochie").

In the appearance of St. Nicholas Cathedral, the author embodied small decoration and a smaller scale of planes, characteristic of temples of the 17 th century, and picturesque composition, which in the 17th century was the opposite of the 16th-century church architecture with simple, slightly decorated symmetrical facades.

It also used the decorative technique of architectural forms that do not reflect the structure.

The echo of the traditions of the 17 th century is also present in the polychrome of St. Nicholas Cathedral: it was in the 17th century that the strict monochrome of the earlier churches (the colour scheme was determined by the combination of building materials brick-stone) was replaced by saturated polychrome with an open colour scheme and the wide use of bright ceramic tiles (thereby, it cannot be argued that the ceramic decor on the facades of St. Nicholas Cathedral is associated with the use of majolica during the Art Nouveau period, such traditions in Russia were earlier).

The St. Nicholas Cathedral is associated with the traditions of the "Moscow pattern-work" by the compositional technique of several tents in the crowning of the volumes of one church when the tent from the ceiling turns into a low decorative crowning of a secondary volume.

In its figurativeness, the St. Nicholas Cathedral is closest to a 17th-century Moscow school, where the idea of a five-domed church with several tiers of kokoshniks came from; however, the architect applied the technique of light drums of all cupolas, while the churches of the Moscow school often had a light central drum and purely decorative smaller cupolas.

In the St. Nicholas Cathedral, another method of the Moscow school was applied and creatively rethought - an additional division of tiers by developed decorated architraves with wide majolica friezes and modified entablements and cornices.

M.T. Preobrazhensky also studied the manifestations of national Russian features in the temples of Yaroslavl and Suzdal of the second half of the 17th century, in particular, he borrowed and rethought the construction of the church's volume with closed galleries and embodied this idea on the eastern facade in the lower tier. Perhaps he borrowed the idea of the cube-shaped volume of the church with five domes there, but he saturated it with decor and contrasted the cube-shaped volume of the church with two tented outbuildings. Despite the strict canonicity of the composition of the St. Nicholas Cathedral, it is successively connected both with the churches of the period of "Russian pattern-work" and with residential chambers of the same time where a similar set of elements was applied; 
it has continuity with the wooden churches of the Russian North, which is expressed in the outline of domes and the use of majolica tiles in the shape of an old-fashioned wooden ploughshare, which was used as a cover for wooden churches in the Russian North.

As already mentioned above, despite the fact that the appearance of the cathedral is a concentration of all the signs characterizing national identity, because of another - the Mediterranean - natural environment - it is perceived quite differently than the temples of Moscow, Yaroslavl or Suzdal. In this case, we can say that it was the natural environment that completely changed the perception of the style of architecture.

\section{Conclusion}

To a large extent, the impressive image of the residence of the Governor of Qingdao (otherwise Qingdao Guest House) created by the aid of the urban development, which helped to transform the building, original in architecture, into an accent element that forms the perception of historical buildings. The installation of the building on the hill with the possibility of its comprehensive review significantly enhances its artistic perception, which is visible by the location of the government residence on the hillslope of Xinhao Mountain (Xinhao Shan, Signal Hill, Dragon Mountain, Dragon's Mountain), facing the sea, thus the formation of the "architectural landscape" actively includes the natural landscape [16]. The building of the governor's residence seems to be standing above the dragon's lair as the mountain itself is called "Dragon", and the roads along the southern slope leading to the residence and connecting it with the foot of the mountain are "dragon's" [16]. The general visual composition involved the water surface with a bridge and a natural relief, and a well-tended landscape park of 26,000 square meters with green terraces.

The dragon in Chinese mythology, philosophy and culture (Chinese trad. 龍, ex. 龙, pinyin: lóng, pall.: moon), unlike the predatory European dragon snake, symbolized the good beginning of the Yang, the Chinese nation, the water element. As the king of animals, the dragon was a symbol of the imperial authority.

On the one hand, foreigners who settled in the city-colonies, first of all, sought to create the image of their homeland, including the landscape gardening art; on the other hand, they had to take into account the specific natural environment, landscape, local flora. Besides, Chinese gardeners were also involved in the landscaping process, and thus the German general methods of organizing the natural environment were superimposed on local park building techniques $[16,17]$.

Understanding the origins of Chinese garden art is impossible without a deep understanding of Chinese philosophy and worldview. The traditional Chinese landscape gardening art in its philosophical content is much more complex and profound than the European landscape gardening art. The first aims at harmonizing area which is an integral part of the Universe; the second serves primarily as a means of aestheticization and harmonization of the architectural environment and, in most cases, it does not contain a philosophical component at the root $[16,17]$. Chinese garden art characterized by the polysemy and symbolism of the created compositions, the smoothness of lines and the freedom of growing plants, their infinity through human interference, the identification of the "hidden meaning" of each plot through small architectural forms, stones, inscriptions of philosophical content located in strictly defined places, the relationship of the natural landscape with different types of art - literature, music and painting (landscape as a principal character of the creation, a person as an additional secondary optional part). During the reign of European Baroque, Romanticism and Art Nouveau in the landscape garden art of Western Europe, some features of eastern parks were inherited: "columns of sadness", obelisks, park pavilions and "ruins" with philosophical names, "Chinese pavilions" and "tea houses" appeared, however, it was only a "Europeanized" external inheritance of a phenomenon alien to the European consciousness without filling it with philosophical meaning.

The example of the Saint Nicholas Cathedral in Nice shows how, thanking a radical variation of the natural environment, such a conservative building as an Orthodox church is changing. The Saint Nicholas Cathedral is an example of the ideal placement of the object in the natural environment when the environment enhances the perception of architecture; the temple is striking by its every non-standard element: the complexity of the dynamic multi-axis volume and spatial composition and the emphasized detailing of the facades and the interiors' decoration. The cathedral, as it were, simultaneously exists in several dimensions - it contains echoes of the ancient Russian traditions in the interior, the "Moscow pattern" on the facades, at the same time it is a temple of the period of historicism-eclecticism and modernity and a temple that exists in our time. 


\section{References}

1. Goriunov, V.S., Tubli, M.P. Architecture of the Art Nouveau era. Concepts. Directions. Masters. St. Petersburg: Stroyizdat, 1992, 360 p.

2. Zabiyako, A.A., Zabiyako, A.P., Levoshko, S.S., Khisamutdinov, A.A. Russian Harbin: Life-building experience in conditions of the Far Eastern frontier / Edited by A.P. Zabiyako. Blagoveshchensk : Publishing house of the Amur State University, 2015, 462 p.

3. Ivashko, Yu.V., Li Shuan. Art Nouveau of Western Europe, Ukraine and China: ways of transformation and implementation. Kyiv : Phoenix, 2015, 152 p.

4. Kirikov B.M., Ivashko Yu.V. The National Romantic style of St. Petersburg, Kyiv and Kharkiv. Budmaister, 2013, No. 4, p. 4-7.

5. Levoshko, S.S. Russian architecture in Mănzhōu. The end of the nineteenth - the first half of the twentieth century. Khabarovsk: Publishing House "Private Collection", 2003, 176 p.

6. Levoshko S.S. The Russian architecture in Mănzhōu. The end of XIX-the 1st part XX century. Habarovsk. Chastnaya kollekciya, $2003.176 \mathrm{p}$

7. Levoshko, S.S. A new view of China on the Russian architectural heritage of Harbin. "Berega”, 2007, issue 7, p. 103 $-104$.

8. Levoshko, S.S. Russian architecture in China of the late nineteenth - the first third of the twentieth century (historical and cultural context, features, influences). Chinese architecture: two views. Moscow - St. Petersburg, 2013, p. $275-$ 292.

9. Levoshko, S.S. Regional specificity in the works of the "Baltic" Russian architects at the turn of the 19 th -20 th centuries. Art Nouveau architecture in the states of Baltic Region. St. Petersburg: NIITIAG RAASN (The Scientific Research Institute of Theory and History of Architecture and Urban Planning of the Russian Academy of Architecture and Construction Sciences), 2013, p. $90-92$.

10. Lisovskii, V.G. Art Nouveau style in architecture. St. Petersburg: "Voskresnyi Den", 2013,480 p.

11. Lisovskii, V.G. Once again about the problem of identification and systematization of the modernist heritage. Art Nouveau architecture in the states of Baltic region. St. Petersburg: NIITIAG RAASN (The Scientific Research Institute of Theory and History of Architecture and Urban Planning of the Russian Academy of Architecture and Construction Sciences), 2013, p.63-64.

12. Cathédrale ortodoxe russe Saint-Nicolas à Nice. Edition cathédrale ortodoxe russe Saint-Nicolas à Nice. Nice, 2017, $66 \mathrm{p}$.

13. Grosa Silvija. Rethinking National Romanticism in the Architecture of Riga at the Turn of the Twentieth Century. Studie on Art and Architecture, 2012, vol. 21( 3-4), p. 56 - 75.

14. Prager Hans Georg. Tsingtau / Qingdao: Deutsches Erbe in China. [Gebundene Ausga-be], 2011.

15. Sadowski Lukasz. Architektura europejska w Chinach od połowy XIX wieku do 1937 roku. Sztuka Dalekiego Wschodu. Studia Warszawa, 2008, p.145 - 154.

16. Wang Chaolu. Fifty Old Constructions in Quingdao. Quingdao Publishing House, 2008,114 p.

17. Yuan Binjiu. German architecture in Oingdao. China Architecture and Building Press, 2009,415 p.

AUTHORS:

Yuliia Vadymivna Ivashko. A historian of architecture and landscape architect. Doctor of Architecture (2013), Professor (2015), Professor, Nostrified doctor habilitatus (2018) Kyiv National University of Construction and Architecture, 31, Povitroflotskyi Avenue, Kyiv, Ukraine.

E-mail: yulia-ivashko@ukr.net

Tetiana Yuriivna Kuzmenko. An urbanist and landscape architect. Candidate of Architecture (2018), Associate Professor. National University "Yuri Kondratyuk Poltava Polytechnic", Educational and Scientific Institute of Architecture and Construction, 24, Pervomaiskyi Avenue, Poltava, Ukraine.

E-mail: tancho286@gmail.com

Li Shuan, An urbanist and landscape architect. Candidate of Architecture (2017), Associate Professor, Zhejiang University of Technology, China. E-mail: 455237029@qq.com

Chang Peng, Post-graduate student, Kyiv National University of Construction and Architecture, 31, Povitroflotskyi Avenue, Kyiv, Ukraine. E-mail:_changpeng2277@gmail.com

Kopsavilkums. Rakstā analizēti vienāda stila objektu pāru piemēri, kas atrodas atškirīgās valstīs. Izvērtēti apsekti, kas saistīiti ar arhitektūras stila ideologisko uztveri, kad objektu stils un izpildījums tiek pārcelts uz citas valsts teritoriju. Analizēti objekti Somijā un Ķ̄̄nā, kā arī Krievijā un Francijā. Raksts ietver informāciju par vispārējo stila noteikšanas pazīmju saglabāšanu, objektu novietojumu pilsētvidē un formu valodu, kas katrā valstīt tiek uztverta atšķirīgi un veidota konkrēta identitāte. 